\title{
Kepemimpinan Transformatif dalam Pendidikan Islam
}

\author{
Ismail Suardi Wekke \\ *Pascasarjana Institut Agama Islam Negeri (IAIN) Sorong, Indonesia \\ **Necmettin Erbakan University, Turki \\ Email: iswekke@gmail.com
}

\begin{abstract}
ABSTRAK
Artikel ini memberikan ulasan terkait Kepemimpinan Transformatif. Secara khusus dalam kajian Pendidikan Islam. Kebijakan pembentukan prodi pascasarjana semasa pengusulan pascasarjana STAIN Sorong diajukan mensyaratkan adanya distingsi tertentu sebagai panduan dalam penyusunan kurikulum. Maka, artikel ini akan menjadi pengenalan terma dan juga mengimbas pada masa lalu, untuk memberikan deskripsi kepada mahasiswa terkait dengan kepemimpinan transformatif. Dimana ini dijadikan sebagai landasan kalaulah bukan sebagai Pola Ilmiah Pokok (PIP) yang menjadi pemandu dalam menjalankan rumpun keilmuan pascasarjana.
\end{abstract}

Kata kunci: Pendidikan Islam, Transformatif, Pascasarjana

\section{Refleksi ke Masa Lalu}

Semasa usulan pendirian pascasarjana STAIN Sorong dikonsultasikan ke Diktis Kementerian Agama, perlu adanya sebuah distingsi dalam penyusunan kurikulum. Dalam proposal kemudian tim memaktubkan "kepemimpinan transformatif". Tim pendirian pascasarjana ketika itu dengan pimpinan STAIN Sorong Prof. Dr. H. Abustani Ilyas, dengan sekretaris tim, Ismail Suardi Wekke, Ph.D.

Usulan ini diterima, dan menjadi distingsi resmi pascasarjana STAIN Sorong yang saat ini sudah bertransformasi menjadi IAIN Sorong. Bahkan dalam kesempatan wisuda sarjana 2015, kasubdit kelembagaan, Dr. H. Mastuki berkenan menyampaikan orasi ilmiah. Sekaligus pada kesempatan tersebut menjadi nara sumber untuk workshop dalam rangka penyempurnaan usulan pascasarjana.

Prodi pascasarjana kemudian menerima mahasiswa baru sejak 2015, secara efektif mulai kuliah 2016 dengan angkatan pertama sebanyak 20 orang. Angkatan ini kemudian berhasil diluluskan walau dengan waktu yang tepat. Alumni Angkatan pertama tersebut, diantaranya Ambo Tang, sementara melanjutkan pendidikan doktor di UIN Alauddin Makassar.

Untuk pembentukan kelembagaan pada masa awal itu, direktur pascasarjana langsung dipimpin Prof. Dr. Abustani Ilyas. Didampingi juga dengan Plt. Sekretaris, Ismail Suardi Wekke, Ph.D. Kemudian 2016 dilantik Dr. H. Surahman Amin, Lc., MA sebagai direktur pascasarjana yang didampingi sekretaris, Ismail Suardi Wekke, Ph.D.

Mengawali pascasarjana 2016, dilaksanakan pulalah sebuah workshop "Pembelajaran berbasis Riset" dengan nara sumber Prof. Dr. Istadi, dan Prof. Dr. Heru Susanto. Keduanya dari Universitas Diponegoro, Semarang. Kegiatan ini dilaksanakan oleh Pusat Penjaminan Mutu STAIN Sorong, dalam rangka memberi kemahiran bagi mahasiswa pascasarjana dalam meneliti sejak dalam perkuliahan.

Begitu pula dalam perkuliahan tidak lagi menggunakan hanya makalah saja, tetapi juga dengan artikel jurnal. Sehingga semasa mengampu mata kuliah bersama dengan Dr. H. Ridha Suaib, Dr. 
Like, dan Dr. Surahman Amin, dalam tiga semester pertama, kesemuanya menggunakan pola artikel jurnal. Bukan lagi sekadar makalah saja.

Ini semata-mata adalah "ijtihad" untuk mengenalkan satu pola penulisan ilmiah. Dimana pascasarjana yang tumbuh dari tradisi Ciputat, masih saja hanya menggunakan makalah saja. Sehingga kalau makalah, akan berakhir pada kumpulan makalah. Tidak terbaca di kalangan publik, padahal dalam penyusunannya menghabiskan ikhtiar yang bolehjadi tidak sekadar menjadi bagian dalam penyelesaian mata kuliah tetapi juga layak dibacak khalayak ramai.

Pada kesempatan berikutnya, terlihat bahwa ketika kemampuan ini dilatihkan, akan menjadi kemahiran yang "bermanfaat". Alumni pasca yang meneruskan pendidikan ke jenjang doktor seperti di UIN Sunan Kalijaga kemudian mendapati bahwa perkuliahan pasca di Yogyakarta bahkan mensyaratkan penerbitan artikel sebagai rangkaian menuntaskan proses belajar dalam mata kuliah.

Walau di IAIN Sorong tidak "seketat" ini, namun sejak awal sudah dikenalkan. Bahkan diantara artikel-artikel kelas tersebut, juga sudah terbit di jurnal terakreditasi. Diantaranya jurnal yang SINTA 2. Ini disebutkan hanya sebagai penjelasan bahwa kemampuan mahasiswa mampu menerbitkan artikel juga sampai pada skala nasional.

Olehnya, tidak boleh menjadi alasan. Bahwa keberadaan di wilayah 3T menjadi penghalang untuk terus belajar. Secara khusus perlu saya kemukakan ini. Dalam satu kesempatan acara perguruan tinggi di Jayapura, alasan yang menjadi mudah untuk dijadikan keluhan ketertinggalan adalah menghuni wilayah $3 \mathrm{~T}$.

Padahal, Tanah Papua dimana matahari paling awal terbit di tanah air. Bahkan bersamaan dengan Jepang yang disebut negeri matahari terbit. Justru sebuah kesempatan untuk berdoa lebih awal, disbanding pulau lainnya di Indonesia.

Perjalanan ke Eropa, September 2021 saya mendengarkan kata Bapak Dr. H. Rustamadji. "Papua adalah tempat paling layak dan paling subur untuk mengeluh. Jikalau saja mengeluh itu menyelesaikan masalah, maka paling pertama kita lakukan adalah dengan mengeluh". Kalimatnya memesankan demikian, walau secara harfiyah, saya yang mengetikkan.

Maka, sebelum melangkah lebih jauh dalam memelajari kepemimpinan transformatif, mahasiswa perlu lebih awal mentransformasikan sikap, perasaan, dan sasaran capaian yang juga melangkah ke hadapan. Saya tidak akan menyebutnya "berkemajuan" jangan sampai itu dilabeli sebagai kata yang berasosiasi ke ormas tertentu.

Walau juga tidak semua, saya secara pribadi tidak menilai hasil pembelajaran dengan soal artikel ini. Bahkan saya secara khusus hanya mensyaratkan kemampuan minimal. Hanya saja, untuk sebuah jenjang pascasarjana, artikel dan juga jurnal merupakan bagian dari ekosistem keilmuan yang perlu dikenali sejak dini.

\section{Masa Depan Pendidikan Islam}

Empat studi kasus yang dapat menjadi bahan kajian untuk melihat transformasi pendidikan Islam.

Pertama, Gontor. Ketika tantangan kontekstual masa itu terkait kemampuan bahasa, maka Gontor melengkapi kurikulumnya dengan kemampuan bahasa asing yaitu Arab dan Inggris. Sejalan dengan perkembangan pembelajaran bahasa modern yang menekankan pada kemampuan 
produktif, tidak hanya pada kemampuan bahasa yang pasif yaitu penerjemahan dan tata bahasa (Wekke, \& Andriansyah, 2016). Begitu pula dengan pengelolaan pendidikan kebahasaan yang menggunakan prinsip-prinsip modern (Wekke, \& Busri, 2016).

Bukan itu saja, pendidikan Islam yang tidak fanatik pada golongan tertentu saja (Kholish, \& Wekke, 2018). Keberadaan Gontor menjadi sebuah titik tolak pendidikan modern Indonesia (Wekke, Umbar, \& Arsyad, 2016). Ini memengaruhi pendidikan Islam di Indonesia secara luas (Wekke, 2015).

Kedua, UIN Maunala Malik Ibrahim Malang. Dunia Islam mengenal pendidikan tinggi berabadabad. Disebutkan bahwa diantara perguruan tinggi terkemuka diantaranya Al Azhar, kemudian juga tersebar di pelbagai kawasan. Sementara akhir abad 20, di Indonesia fenomena UIN Malang yang diawali dari fakultas filial IAIN Sunan Ampel. Tak lain, diantaranya soal kepemimpinan (Wekke, \& Farwa, 2018).

Ketiga, UniMUDA Sorong, Muhammadiyah Papua. Kewujudan Muhammadiyah di Papua memerankan posisi lintas keagamaan (Wekke, Arif, Zubair, \& Wardi, 2019). Pendidikan menjadi amal usaha yang utama dan pertama (Tahang, Wekke, \& Fatimah, 2019).

Gerakan Muhammadiyah menjadi tindakan akseleratif untuk menjadi gerakan keumatan (Wekke, Barulazi, Rais, \& Idris, 2019). Tanpa meninggalkan peran-peran dakwah (Barulazi, Wekke, \& Rais, 2019). Diantara amal usaha itu, Universitas Pendidikan Muhammadiyah Sorong (Pratikno, Rasyid, \& Wekke, 2021).

Keempat, Emeyodere. Sebagai sebuah prakarsa untuk menyediakan pendidikan secara luas. Emeyodere didirikan sebagai solusi. Bukan lagi hanya dengan mengeluh (Widodo, \& Wekke, 2020). Ada semangat belajar yang mengiringinya (Wekke, Ruaidah, \& Wardi, 2019). Begitupula dengan keberadaan kepemimpinan yang situasional (Wihayuningtyas, Amin, \& Wekke, 2021).

\section{Implikasi Teoritis}

Pesantren dan lembaga Pendidikan Islam lainnya mengalami transformasi dengan integrasi kelimuan ataupun wacana. Diantaranya dengan memasukan isu kewirausahaan (Wekke, 2012). Dengan isu ini, menjadikan pesantren tidak lagi hanya soal keagamaan semata, tetapi bagaimana menghidupkan suasana keagamaan (Wekke, 2017).

Pesantren membuka diri terhadap teknologi (Wekke, \& Hamid, 2013). Termasuk modifikasi dalam pembelajaran Bahasa Arab (Yusuf, \& Wekke, 2015). Begitu pula dengan isu-isu multikulturalisme (Wekke, \& Lubis, 2008). Juga menjadi perjuangan untuk pemberdayaan (Wekke, 2016). Semuanya mengalami kontruksi dari waktu ke waktu (Wekke, 2014). Kata kunci di sini adalah kepempinan (Salim, Wekke, \& Sunatar, 2012).

\section{Penutup}

Artikel ini mengemukakan bagaimana pendidikan Islam mengalami transformasi. Ada sebuah kondisi kontekstual yang menjadi pengiring sehingga menjadi "daya desak" untuk mewujudkannya.

Hanya saja, dalam setiap kelembagaan terlihat adanya soal kepemimpinan yang menjadi daya gerak organisasi sehingga bisa mengikuti ritme tuntutan dan juga pemenuhan tantangan atas kondisi yang ada. 


\section{Daftar Pustaka}

Barulazi, B., Wekke, I. S., \& Rais, M. (2019). Gerakan Dakwah Muhammadiyah di Kota Sorong. https://doi.org/10.31227/osf.io/hycdg.

Kholish, M., \& Wekke, I. (2018). " Fiqh education based on internal tolerance of religious society of religious ideology variance". International Journal of Pure and Applied Mathematics, 119 (18), pp. 1033-1043.

Pratikno, M., Rasyid, M. R., \& Wekke, I. S. (2021). Leadership of the Principal on Laboratory Elementary School of Unimuda Sorong in Improving the Quality of Education. https://doi.org/10.31219/osf.io/nv52g.

Salim, A. Wekke, I. S. \& Sunatar, B. (2012). Pengaruh Komunikasi Persuasif Dalam Meningkatkan Motivasi Kerja di Sekolah Tinggi Agama Islam Negeri (STAIN) Sorong. Skripsi. Sorong: STAIN Sorong. https://doi.org/10.13140/RG.2.2.28855.47520.

Tahang, H., Wekke, I. S., \& Fatimah, F. (2019). Dakwah Muhammadiyah Melalui Lembaga Pendidikan. https://doi.org/10.31227/osf.io/scjnq.

Wekke, I. S. \& Farwa, H. (2018). Kepemimpinan Transformatif Perguruan Tinggi Islam. Yogyakarta: Penerbit Gawe Buku.

Wekke, I. S. (2012). Pesantren dan pengembangan kurikulum kewirausahaan: Kajian pesantren roudahtul khuffadz sorong papua barat. Inferensi: Jurnal Penelitian Sosial Keagamaan, 6(2), 205-226.

Wekke, I. S. (2014). Tradisi pesantren dalam konstruksi kurikulum bahasa Arab di lembaga pendidikan minoritas muslim Papua Barat. KARSA: Journal of Social and Islamic Culture, 22(1), 20-38.

Wekke, I. S. (2015). Antara Tradisionalisme dan Kemodernan: Pembelajaran Bahasa Arab Madrasah Minoritas Muslim Papua Barat. Tsaqafah, 11(2), 313-332.

Wekke, I. S. (2016). Religious education and empowerment: study on pesantren in muslim minority West Papua. MIQOT: Jurnal Ilmu-ilmu Keislaman, 37(2).

Wekke, I. S. (2017). Integrasi Pendidikan Islam dan Pembelajaran Kewirausahaan di Pesantren Minoritas Muslim. Fenomena, 9(1), 1-24.

Wekke, I. S., \& Andriansyah, A. (2016). From Gontor to Sorong: Muslim Minority Practices on Arabic Teaching and Learning. Sosiohumanika, 9(1).

Wekke, I. S., \& Busri, M. (2016). Kepemimpinan Transformatif Pendidikan Islam: Gontor, Kemodernan, dan Pembelajaran Bahasa. Yogyakarta: Deepublish.

Wekke, I. S., \& Hamid, S. (2013). Technology on language teaching and learning: a research on Indonesian pesantren. Procedia-Social and Behavioral Sciences, 83, 585-589.

Wekke, I. S., \& Lubis, M. A. (2008). A Multicultural approach in Arabic language teaching: creating equality at Indonesian pesantren classroom life. Sosiohumanika, 1(2).

Wekke, I. S., Arif, B., Zubair, A., \& Wardi, M. (2019). The Role of Muhammadiyah Institution Towards Muslim Minority in West Papua. Jurnal Ilmiah Peuradeun, 7(1), 21-42.

Wekke, I. S., Arif, B., Zubair, A., \& Wardi, M. (2019). The Role of Muhammadiyah Institution Towards Muslim Minority in West Papua. Jurnal Ilmiah Peuradeun, 7(1), 21-42.

Wekke, I. S., Barulazi, B., Rais, M., \& Idris, I. (2019). Akselerasi Gerakan Dakwah Muhammadiyah di Wilayah Minoritas Muslim Papua Barat. https://doi.org/10.31227/osf.io/7n9bj.

Wekke, I. S., Ruaidah, F., \& Wardi, M. (2019). The Growth of Learning Enthusiasm at the Emeyodere Moslem Minority Education Institution in West Papua. Nadwa: Jurnal Pendidikan Islam, 12(2), 363-386.

Wekke, I. S., Umbar, K., \& Arsyad, A. (2016). Tradisionalisme dan Modernisme Pembelajaran Bahasa Arab: Pembelajaran Madrasah Berbasis Pesantren Minoritas Muslim. Prosiding Konferensi Nasional Bahasa Arab, 1(2).

Widodo, S., \& Wekke, I. S. (2020). Yayasan Emeyodere dalam Pelayanan Pendidikan Masyarakat Kokoda di Kota Sorong. Yogyakarta: Deepublish. 
Wihayuningtyas, N., Amin, S., \& Wekke, I. S. (2021). Kepemimpinan dalam Memperjuangkan Pendidikan Bagi Minoritas Muslim Papua. Yogyakarta: Bintang Pustaka Madani.

Yusuf, M., \& Wekke, I. S. (2015). Active learning on teaching Arabic for special purpose in Indonesian Pesantren. Procedia-Social and Behavioral Sciences, 191, 137-141. 